\title{
Metastasis: imaging shows the way
}

\author{
Hellmut Augustin ${ }^{1,2^{*}}$, Jonathan P Sleeman ${ }^{2,3}$ \\ From International Cancer Imaging Society (ICIS) 14th Annual Teaching Course \\ Heidelberg, Germany. 9-11 October 2014
}

Metastasis, the life threatening aspect of cancer, is a systemic disease process. Considerable progress has been made in recent years regarding how tumor cells circulating in the blood and lymphatic systems interact with and extravasate into secondary sites, and what determines whether these disseminated tumors cells survive, remain dormant or go on to form macrometastases. New insights into the routes that tumor cells take once leaving the primary tumor have emerged. Novel concepts regarding early seeding of metastases coupled to parallel progression, self-seeding of primary tumors by circulating tumor cells, and the induction of pre-metastatic niches in distant organs by primary tumors have come to the fore. In our presentations we will review these and other paradigm shifts that have taken place over recent years, placing a particular focus on how the use of intravital and other imaging techniques have played a major role in these developments.

\section{Authors' details}

'DKFZ, Im Neuenheimer Feld 280, 69121 Heidelberg, Germany. ${ }^{2}$ Medical

Faculty Mannheim, CBTM, Ludolf-Krehl-Str 13-17, 68167 Mannheim, Germany.

${ }^{3}$ KIT Karlsruhe, Hermann-von-Helmholtz-Platz 1, 76344 Eggenstein-

Leopoldshafen, Germany.

Published: 9 October 2014

Submit your next manuscript to BioMed Central and take full advantage of:

- Convenient online submission

- Thorough peer review

- No space constraints or color figure charges

- Immediate publication on acceptance

- Inclusion in PubMed, CAS, Scopus and Google Scholar

- Research which is freely available for redistribution

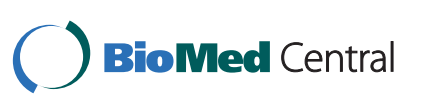

(C) 2014 Augustin and Sleeman; licensee BioMed Central Ltd. This is an Open Access article distributed under the terms of the Creative Commons Attribution License (http://creativecommons.org/licenses/by/4.0), which permits unrestricted use, distribution, and reproduction in any medium, provided the original work is properly cited. The Creative Commons Public Domain Dedication waiver (http://creativecommons.org/publicdomain/zero/1.0/) applies to the data made available in this article, unless otherwise stated. 